\title{
The Defence and Citizenship Day (JDC) in France
}

\section{Systematic identification and monitoring of young adults facing literacy difficulties stimulates closer cooperation between state administrations and civil society in the field of literacy}

\author{
Jean-Pierre Jeantheau
}

Received: 10 May 2016 / Accepted: 6 July 2016/ Published online: 11 August 2016

(C) The Author(s) 2016. This article is available at SpringerLink with Open Access.

\begin{abstract}
The JDC (Defence and Citizenship Day) has become an essential element in the fight against illiteracy in France. It not only furnishes annual statistics for national, regional and local policy evaluation, but also identifies those young adults within a entire cohort (mostly 17-19) who need help with their literacy skills, so that they can be referred to by support organisations.

It is difficult to assess very precisely the impact of post-JDC actions carried out by JDC partners. Neither the JDC tests nor the post-JDC actions are perfect, but through growing cooperation between the numerous stakeholders federated with the JDC the efficiency of each partner increases, and the global effort becomes more productive. The JDC impact is far more than literacy test results. It is also the discovery of other partners, the exchange of points of view and practices, the research into coordination of action to increase global effectiveness.

The JDC experience shows that it is possible to investigate literacy problems, and to identify instances of illiteracy in a nationwide programme that is not principally literacy-oriented. This is a way to make public investment more efficient and to create support for synergies between organizations working in the literacy field.
\end{abstract}

\section{Introduction and general background}

\subsection{Foundations}

Although learning to read and write has been going on for several millennia, the aim of extending this to the entire population is more recent. In France, in the period now known as the "Enlightenment", this objective gave rise to great philosophical

J.-P. Jeantheau $(\bowtie)$

French national agency for fighting illiteracy, Lyon, France

E-Mail: jean-pierre.jeantheau@anlci.fr 
debates. Condorcet had the last word, and his writings during the revolutionary period remain educational guidelines to this day. However it was not until the 1830s that the French government invested in a sustainable way (Condorcet 1791) in primary education, and not until the late 19th century that all children were compelled by law to attend primary education (Furet and Sachs 1974).

The spread of "alphabetization" was quantitatively monitored in censuses (from 1866 to 1946), and during the process of recruitment of army conscripts (since 1829). Taking into consideration the results of the first post WWII census, which showed an illiteracy rate of $3.4 \%,{ }^{1}$ the government thought that the problem of illiteracy had disappeared in France following the introduction and gradual lengthening of compulsory schooling. ${ }^{2}$ The only illiterates ${ }^{3}$ still present on metropolitan soil were, according to the authorities, migrants. In the post-war context (reconstruction, full employment, and economic growth) non-mastery of the written language by people schooled in France was not an issue. For a long time, French society has tacitly accepted a more or less considerable "residual" percentage of people unable to read or write. This acceptance was less moral than economic, since many illiterate individuals hid their situation, by not registering for courses which could have reduced their number but which, at the same time, would certainly have revealed their difficulties. Because people who remained illiterate had attended school programmes which were intended to ensure that they acquired basic reading and writing skills, it was difficult to identify them from official figures.

\subsection{The bad news: the "Illettrisme"}

In the 1970s the illiteracy problem became more obvious for the authorities, when an increase in unemployment, accompanied by substantial economic restructuring plans, began leading to the disappearance of the kinds of jobs that had previously been a source of income for people with poor writing skills. Unemployed people were at this time offered training schemes for which writing skills were assumed to have been acquired. Illiterates therefore became excluded from the job market, and most of them saw their situation become more complicated. Their time in unemployment increased in comparison with the average, and economic difficulties became more common.

Associations working in contact with people in difficulty definitely started to notice the (hitherto) invisible cases of illiteracy. In the late 1970s, the NGO ATD Fourth World (Aide à Toute Détresse Quart Monde), wishing to distinguish, among the individuals facing literacy problems, the population which had been educated in France from those who had arrived as immigrants, reintroduced into public debate the term "Illettrisme", a term which is still in use today (Espérandieu and alii 1984).

\footnotetext{
1 Self-declaration, persons aged over 10 years.

2 On 9 August 1936 the law increased the age of compulsory schooling to 14 years and on 6 January 1959 to 16 .

3 Following the Unesco terminology in use at the time.
} 
From the very beginning, according to those who reintroduced the term, "Illettrisme" referred to illiteracy as defined by Unesco in $1958,{ }^{4}$ and at the same time to a French-speaking individual schooled in France. These last characteristics are the basis of the distinction between "illettrés"5 and other illiterates (mostly immigrants who have not been at school in France), and also of the necessity for different and specific remedial action. In 2003, the National Literacy Agency (ANLCI, Agence nationale de lutte contre l'illettrisme), and around one hundred national stakeholders working in the literacy field, following the same pattern, offered a precise official definition of illiteracy (ANLCI 2003).

\subsection{Historical background}

Because the French Army has a long tradition of providing literacy courses for soldiers, since the end of the 18th century and the creation of the National Army (Republican at first), for decades literacy and numeracy courses, typically taught by recruits with a teacher qualification, were provided for army recruits experiencing difficulties in these areas. Before 1997, conscripts undertook basic skills tests. In the 1980s famous French sociologists used the test results to assess changes in the level of performance of young people (Baudelot and Establet 1988). This monitoring continued until the suspension of compulsory military service in 1997.

The suspension of conscription raised a number of concerns including: the need to hire professional soldiers in place of conscripts, and the end of pedagogical support for young adults (men) facing literacy difficulties. The Military Registration Day (Journée d'Appel de Preparation à la Défence, JAPD) was conceived as a way of tackling those concerns. For several reasons, mainly financial, an original plan to have 3 conscription days during which a broad range of knowledge and skills would be assessed was abandoned in favour of a single day and with assessment of reading literacy only. The resulting reading tests focussed on identifying participants with low literacy levels.

The JAPD was implemented for the first time in 1998. Originally intended for male adolescents it was extended to include females in 2000. The name changed on $1^{\text {st }}$ July 2010 to become the JDC, but operating methods remain the same. In the following text we will use the acronyms JAPD or JDC depending on circumstances.

JAPD has from the beginning been considered by the Ministry of Education as a unique opportunity to identify young people emerging from compulsory education still facing difficulties with reading and writing. Importantly, JAPD offered, for many, a last possibility to benefit from monitoring and support to improve their literacy skills. JAPD thus has an important role in the fight against adult illiteracy in France. Indeed, following the definition of Illettrisme, young adults who fail JAPD tests could be considered as "in a situation of Illettrisme", because they are facing literacy difficulties even though they have been educated in France (migrants do not attend JAPD-JDC).

\footnotetext{
4 "A literate person is one who can, with understanding, both read and write a short simple statement in his or her everyday life" (UNESCO 2006, Education for All Global Monitoring Report, p. 153).

5 Today, officially, "person in a situation of illettrisme" is used instead of "illettré".
} 


\subsection{The French "journey to citizenship"}

The JDC is the last step of the Parcours citoyen (Journey to citizenship). The journey begins in the secondary school, with information courses about the functioning of French democratic society and citizens' duties. The next step is the census at age 16 in City hall, while the final step is the JDC.

Registration is compulsory for boys and girls at age 16. Personal data relating to youngsters who have fulfilled the registration procedures are sent to the Military administration, to the Office for military service (DSN). The National and Regional Service Offices (DSN and CSN) collect the data and plan JDC sessions. They send each registered youngster a written notification to attend the $\mathrm{JDC}^{6}$. The date proposed by DSN can be modified by agreement between the CSN and the future participant. The Army pays for transport, and offers breakfast and lunch to participants.

By virtue of this process, JDC participants are typically between 17 and 19 years old (maximum 25). While participation in JDC is not compulsory, a certificate attesting to participation is required when applying for any state diploma, including a driving licence, and so the participation rate is very high, at around $95 \%$. The JDC certificate is given to each participant whatever his/her test results are.

In 2016, to tackle the growth of fraudulent JDC participation certificates the Ministry of Defence is developing an electronic certificate which can be consulted on its website. When needed, young adults will be able to provide administrations with a link to their certificate.

\subsection{Practical considerations about JDC}

In 2015, 9105 personnel belonging to all branches of the army, including $18.5 \%$ of reservists, administered JDC tests to 795,293 young adults (mainland and overseas) in 282 sites ( $70 \%$ of all military sites). Table 1 shows a steady increase in the numbers of JDC participants over recent years, along with a relatively stable cohort participation rate.

The global budget of JDC in 2015 was just over 110 mio. $€$. This cost included postage, participants' transport costs, accommodation, salaries of Defence civil servants, extra bonus, and all costs paid directly for the organization of the JDC, including testing. Table 2 shows that the JAPD-JDC cost per participant has

Table 1 JDC participation from 2010 to 2015. (Ministry of Defence, DSN, Office of National military service 2015)

\begin{tabular}{lllllll}
\hline Years & 2010 & 2011 & 2012 & 2013 & 2014 & 2015 \\
\hline Attended JDC & 725,347 & 752,059 & 748,546 & 763,842 & 783,266 & 795,293 \\
Eligible $^{\mathrm{a}}$ for JDC & 837,757 & 860,159 & 833,889 & 881,285 & 889,478 & 895,822 \\
Participation in \% & 86.6 & 87.4 & 89.8 & 86.7 & 88.1 & 88.8 \\
\hline
\end{tabular}

${ }^{a}$ Eligibility is higher than a generation (between 750,000 to 800,000 ) because of possibilities to postpone JDC attendance from one year to another

\footnotetext{
6 Young adults with disabilities have the possibility of cancelling their participation in JDC.
} 
Table 2 Variation of average cost per participant. (Parliament and DSN (Ministry of Defence))

\begin{tabular}{lllllllll}
\hline Years & 2006 & 2007 & 2008 & 2010 & 2011 & 2012 & 2013 & 2014 \\
\hline Average Cost in $€$ & 190 & 182 & 195 & 157 & 149 & 144 & 142.50 & 139.64 \\
\hline
\end{tabular}

Table 3 Variation in the JDC satisfaction rate. (Government (LOLF) and DSN (Ministry of Defence))

\begin{tabular}{lllllllllll}
\hline Years & 2006 & 2007 & 2008 & 2009 & 2010 & 2011 & 2012 & 2013 & 2014 & 2015 \\
\hline $\begin{array}{l}\text { Satisfaction } \\
\text { rate in \% }\end{array}$ & 91.10 & 90.70 & 90 & 90 & 84.40 & 85.50 & 86.20 & 87.73 & 88.50 & 89.80 \\
\hline
\end{tabular}

decreased over time, as a result of a constant effort to rationalize. For a minimum cost JDC action can reach almost a whole cohort.

In accordance with law, ${ }^{7}$ a JDC performance indicator is calculated every year. This is based on participant satisfaction calculated at national level. At the end of the JAPD, participants are invited to fill in a questionnaire, recording their global satisfaction as well as their levels of satisfaction with each of a range of different aspects, including the notification to attend, the welcome, breakfast, contacts with Defence civil servants, etc. Table 3 shows that the effort to rationalize lowered the satisfaction rate (DSN interpretation), although this has increased again in recent years.

The specific costs of testing are very difficult to evaluate because the JDC is not solely organized for the identification of young adults facing literacy difficulties. The JDC would be organized even if there were no tests proposed. In 2009, the cost we can identify is half an hour of work (civil servant or non-commissioned officer) for every 40 participants in the testing phase, and around 20 minutes more for each youngster identified as having literacy difficulties. The cost of the materials (screens, computers, individual remote control instruments, documents provided to attenders) and the time for data processing (carried out free by the Ministry of Education) has to be added. The testing costs are not publicly available, only the average cost per participant is published in the national budget adopted by parliament.

\section{JDC literacy ${ }^{8}$ tests}

\subsection{Tests background}

During the JDC, participants receive, amongst other things, an overview of careers in the military and, since 2016, information about young people's rights to vocational and/or basic training. The information presentations target the whole young adult population. Nevertheless, by using literacy test(s) (all participants are put through these) the JDC also aims to identify youngsters who have a very low level of literacy and are still at school, or early leavers with a low level of literacy. In the 1997 law, the

\footnotetext{
7 LOLF, Organic Law on the Finance Laws of 1 August 2001.

8 The term 'literacy' is an exaggeration because in practice, as in OECD surveys, writing is not evaluated, even though the UNESCO and OECD definitions of literacy also include the ability to write.
} 
article 114-3 states: "On this occasion [JAPD] ${ }^{9}$ evaluation tests of basic mastering of the French language are organized." 10

In the same year, the first literacy tests were designed by A. Bentolila's team (University of Paris V Sorbonne) for lower levels of literacy, and by the author for the screening and higher literacy level tests (Jeantheau and Murat 1999). The testing was in two parts: a screening test given to all participants in the morning, and in the afternoon two specialized tests; one for those identified as probably having literacy difficulties (low level test) and one for the rest (high level test). The tests were scored by JAPD staff after each session with the help of an optical reader. After the scoring of the second test young adults identified as having literacy problems were directed to an interview with the person in charge of the test session to discuss their future and to be informed about the possibilities available to improve their literacy levels. The scoring was a critical phase of the evaluation process, it was time-consuming for staff and coding errors were often detected. The process of double testing (morning and afternoon) was a priori the most accurate, but forced postponement to the end of the day of the interviews with youngsters who had literacy difficulties.

In 2003, the organisation of the testing changed. Because of a general reorganisation of the JAPD, the time allocated to tests had to be reduced by half. A single new test was used. It was designed under the responsibility of Ministry of Education by J.-E. Gombert from Rennes II University. The Ministry of Defence remained in charge of the testing process in the field. The new test focuses on word recognition, vocabulary knowledge, and reading comprehension - of an everyday life document a movie theatre programme and short continuous texts (one page extracted from a book). The principle of the final interview determined by the test score was preserved. A controversy was caused inside the Ministry of Education by this test because a lot of teachers did not agree with the test's focus. Moreover, the introduction of a new test (substantially different from the initial ones) broke the statistical data series preventing comparison over time, and raised a new concern for stakeholders.

In January 2009, the testing was automated by the introduction of new technology, including a video film presenting the stimulus materials and associated questions, with a computer capturing the participants' responses through individual remote controls. Test scores are instantly calculated by the computer, and participants' literacy profiles immediately available. In 2015, the final interview process was extended to young adults no longer at school.

The modifications in the test procedures were introduced to meet the governmental cost cutting policy. For the same reason the office administering of the JDC, the DSN, is to be re-organized following a long-term plan (at least 4 years) which focuses on the reduction of the number of staff, mainly by reducing the administrative levels in administration, and the number of offices. The first stage began in 2009. Nevertheless, in 2016, there are no plans to abolish the JDC tests or to cancel the operation.

\footnotetext{
9 Add by the author.

${ }^{10}$ Law n ${ }^{\circ} 97-1019$ on 28th October 1997.
} 


\subsection{Test administration and interpretation of results}

In 2016, as from the beginning, the JDC tests are being administered collectively in classrooms of a maximum of 40 young people, due to the huge number of young people to be tested each year (nearly 800,000). They are administered in specially equipped rooms, most often within military facilities. As of 2009, after an experimentation phase, the test procedure (response capture and processing) has been largely automated to facilitate operations and keep a better record of each young person's responses. JDC personnel give an overview of the course of the testing and ensure that the session runs correctly, then a video begins. Additional instructions for answering questions are given by a character in the video; the youngsters being tested respond via a remote control box nicknamed "Zappette". Each "Zappette" is numbered and its user is identified on the computer in charge of collecting the emitted signals.

When the test process has started it is no longer possible for the young people being tested to go back or modify an answer. For the first exercise words are shown one after the other; the young people having to indicate by yes or no if the words exist in French. The time allowed for a response is very short, a few seconds only. Each word is read aloud by the presenter on video. This vocabulary exercise includes 40 items divided into two groups of 20 presented in two separate blocks. In another exercise pairs of differently spelled words are presented, and the testees have to indicate quickly by yes or no whether the two words are pronounced the same. The last two exercises focus on reading comprehension. They are multi-choice tests. Each youngster gets a hard copy of the stimulus texts. The questions are presented orally. For the first comprehension exercise, youngsters have to understand the information in a cinema programme, often at a simple level. The response time is about 20 seconds, reading the question included. For the last exercise, the young adults have to answer more grammatical questions (for example determining the person represented by a pronoun) in a continuous text (a book excerpt). The results of the tests are immediately available for the staff on-screen at the end of the session.

Analysis of the JDC results does not use Item Response Models, because JDC is solely an identification campaign, and not a literacy survey. Political stakeholders want to know, as precisely as possible, in France but also in other local areas (regions; counties, towns) how many young adults have literacy difficulties, and at the same time they want to offer them ways to improve their literacy levels. The American experience in the NAAL survey (National Research Council 2005), confirmed the appropriateness of this choice.

In the JDC, since the beginning, profiles have been built according to the participants' scores. Since 2003, the participants have been categorized into 5 literacy profiles taking into account their scores in each different exercise. Profile 5 groups together those who succeeded in the comprehension exercises. Profiles 1 and 2 group together young adults facing the most serious difficulties, while Profiles 3 and 4 group together those facing some difficulties.

The Ministry of Education publications give the JDC cohort results across the 5 profiles. The ANLCI considers that profiles 1 and 2 correspond to the literacy level of "illettrisme", and publishes the total of profiles 1 and 2 as indicative "illettrisme" 
Table 4 JDC Profiles in 2015. (DSN and Ministry of Education. Area: Metropolitan France and overseas regions)

\begin{tabular}{|c|c|c|c|c|c|c|c|}
\hline Profile & $\begin{array}{l}\text { Reading } \\
\text { compre- } \\
\text { hension }\end{array}$ & $\begin{array}{l}\text { Word } \\
\text { recogni- } \\
\text { tion }\end{array}$ & $\begin{array}{l}\text { Vocabulary } \\
\text { knowl- } \\
\text { edge }\end{array}$ & Boys & Girls & Overall & $\%$ \\
\hline $5 d$ & $X$ & X & $\mathrm{X}$ & 66.5 & 71.7 & 69.0 & \multirow{2}{*}{$\begin{array}{l}\text { Efficient readers } \\
80.7\end{array}$} \\
\hline $5 c$ & $X$ & $\mathrm{O}$ & $\mathrm{X}$ & 13.4 & 9.7 & 11.7 & \\
\hline $5 b$ & $X$ & $X$ & $\mathrm{O}$ & 6.0 & 7.7 & 6.8 & \multirow{2}{*}{$\begin{array}{l}\text { Mediocre readers } \\
9.4\end{array}$} \\
\hline $5 a$ & $X$ & $\mathrm{O}$ & $\mathrm{O}$ & 2.8 & 2.4 & 2.6 & \\
\hline 4 & $\mathrm{O}$ & $X$ & $X$ & 3.6 & 3.0 & 3.3 & \multirow{2}{*}{$\begin{array}{l}\text { Readers facing } \\
\text { difficulties } \\
5.6\end{array}$} \\
\hline 3 & $\mathrm{O}$ & $\mathrm{O}$ & $\mathrm{X}$ & 3.0 & 1.5 & 2.3 & \\
\hline 2 & $\mathrm{O}$ & X & $\mathrm{O}$ & 1.7 & 1.9 & 1.8 & \multirow{2}{*}{$\begin{array}{l}\text { Readers with strong } \\
\text { difficulties } \\
4.3\end{array}$} \\
\hline 1 & $\mathrm{O}$ & $\mathrm{O}$ & $\mathrm{O}$ & 3.0 & 2.0 & 2.5 & \\
\hline
\end{tabular}

$O$ failed, $X$ validated

figures. Table 4, published by the Ministry of Education, illustrates the way the groups are built, and provides figures for boys, girls and the whole target population according to the different profiles. It shows that, in $2015,9.9 \%$ of the 795,293 young people who took the tests had reading problems: $4.3 \%$ showed strong difficulties (situation of "illettrisme" according to ANLCI definition) and 5.5\% difficulties, according to the Ministry of Education classification.

\subsection{Post-test protocol}

After the reading test, young adults who have been detected as having a problem are given the opportunity to meet with an adult to discuss their future, in a context that is different from the one they are familiar with at school. In 2013, $64.2 \%$ of youngsters with literacy difficulties accepted the offer. In 2016, the interview is being offered not only to young people with poor results but also to early school leavers identified during the JDC registration. This interview provides an opportunity to inform the individuals concerned of the possibilities available to help them improve their literacy skills, and can be continued through guidance and support activities offered by the educational system if the youngsters are still at school or by local Youth Centres (Missions locales) or other bodies if they have left school. This essential aspect of the JDC is discussed further in part 4 (Monitoring post JDC Issues) below.

\section{JAPD-JDC statistics}

\subsection{JAPD-JDC statistics: the limitations}

The JDC tests have been primarily designed to identify young adults facing literacy difficulties. However, the collection of electronic data relating to the majority of the individuals $(95 \%)$ in a cohort could be considered a rich resource for other statistical 
exploration. A careful analysis of the data files can show that the statistical situation is not so clear. Firstly, the number of young adults identified as facing literacy difficulties is very small, ranging from $10 \%$ according to the Ministry of Education criteria to $4 \%$ according to the ANLCI criteria, so very sensitive to any modification of factors. In this context we can observe that $5 \%$ of each cohort do not attend the JDC. This is a very small proportion of the target population, but it could be suspected that this subsample is special because the individuals within it cannot receive diplomas or a driving licence, and cannot enter for competitive examinations to enter public services. Yet no concrete study exists that can demonstrate such facts. Another problem is that the JDC statistics are based on the civil year (from January to December) whereas students work (for exams for instance) over an academic year. A change in the academic schedule or local circumstances can introduce a change in student organisation for JDC participation (application for postponement for example). The consequence is a change from one year to another in the average age of JDC participants. Experience shows that, when the average age increases, the test performance and hence the results decrease (more participants are identified as having literacy problems). The effect is not so strong from one year to another at the national level, but could be more significant at regional or department level. These effects limit the possibilities of comparisons from one year to the next in the same department. It is therefore recommended to evaluate trends over a longer period.

As previously mentioned, before the testing was automated errors arose mainly from human mistakes or from scanning problems during the scoring of multiplechoice response forms. As a result of these problems, during the early years of the JAPD national statistics had to be based on sample data. ${ }^{11}$

With automation and the consequent elimination of scanners these types of error no longer occurred. But other issues emerged. Very rarely, it may happen that a "zappette" (the remote control for transmitting participant responses to the computer) breaks down during the testing process ${ }^{12}$. Apart from technical problems, automated assessment suffers from difficulties with the methodology used (linked to the technology). The collective assessment prevents individuals (indeed the whole group) going back a step, and correcting an initial response if they later judge it to be wrong. For the same methodological (or technical) reasons, the assessment is punctuated by response times that are generally sufficient but that may seem short for someone who is a little slow (for example reflecting intensely before answering) or who was upset by a prior question or the test conditions. Moreover, as the technology enforces the use of multiple choice questions, it is possible with luck to guess correct answers and achieve an acceptable score. This is especially the case for exercises on automated reading or vocabulary in which the answer choices are binary.

Another difficulty: establishing profiles. Looking back at Table 4, we see that the distinction between profiles $1-4$ and profile 5 is based only on reading compre-

\footnotetext{
11 For two or three days fixed in advance all the coaching staff were deployed to ensure optimal procurement conditions and the results of these three days (several thousand tests) were used to calculate the national scores.

12 The proper functioning of "zappettes" is systematically tested prior to the testing.
} 
hension. The distinction between profiles "facing difficulties" and "facing serious difficulties" is based only on vocabulary. The consequence is that one can find readers considered as having no problems with reading despite having failed to show adequate word recognition or vocabulary knowledge (profile 5a), which is somewhat paradoxical.

These issues raise the question of the reliability of individual results and the summary statistics based on them. Solutions were found by trying to address the question of validity.

Regarding the individual scores, the only issue is the identification of a person as a non-fluent reader. For people wrongly identified as having difficulties (a false positive), a first filter consists of the personal interview that takes place during the JDC. Often during this interview the JDC administrators realize the error and do not send the report to the relevant authorities. If nevertheless the erroneous record is sent to the post-JDC authorities, they will realize the error and will not attempt to set up a special monitoring exercise.

The most problematic case is when a youngster facing reading difficulties is not identified by the tests (a false negative). No action will be triggered and it can only be hoped that other social or educational authorities will identify the problem and offer support. In 2016, the new arrangements which establish a post-test interview with all early school leavers, regardless of their tests results, will also reduce the occurrence of this situation.

\subsection{Comparison between JAPD and IVQ statistics}

In 2008, the ANLCI and the INSEE (Institut national de la statistique et des études économiques, National Institute for Statistics and Economic Studies), with the cooperation of the local administration of the Ministry of Defence, carried out a study to compare JAPD tests with tests used in the French adult literacy survey, IVQ (Information et Vie Quotidienne, Information and Everyday Life ${ }^{13}$ ), which are considered as the guidelines, in France, for identifying persons facing literacy difficulties (Jeantheau and Guillon 2010). The results of the study showed that $61 \%$ of young people were placed in the same category by both tests.

Young people identified as having poor literacy by IVQ but not according to the JAPD test ( $15 \%$ of the sample) were mostly those who had learning problems during their school years, and among them there was a higher proportion of early school leavers (some passed the JAPD test solely by chance). Young people identified as having poor literacy by the JAPD tests but not in the IVQ survey (24\% of the sample) had had fewer problems at school, but had a problem with the reading test because of the time limit (some were stressed out by the evaluation method used).

By contrast, the overall figures produced by the two tests were quite close. In 2011, in Metropolitan France, JDC (profiles 1 and 2): $4.3 \%$, for the IVQ population aged below 25 years and schooled in France $4.1 \%$ (profiles 0,1 and 2). This can be checked at regional level in Fig. 1 when the IVQ sample is restricted to persons below 25 years.

13 See Jeantheau (2006, 2014). 


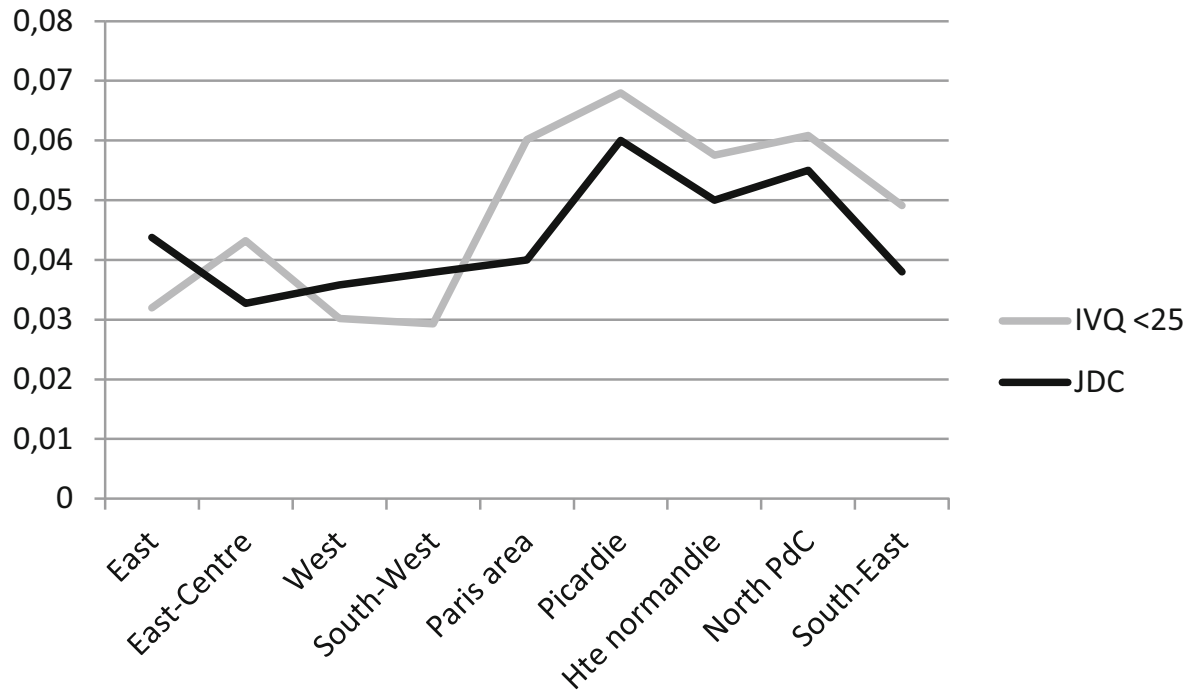

Fig. 1 Comparison of JDC and IVQ for young adults under 25, by region, 2011 (Note 1: the IVQ figures correspond to profiles 0,1 and 2 for people schooled in France whatever their nationality, JDC figures correspond to profiles 1 and 2., Note 2: The IVQ sample is a stratified random sample comprising 13,847 individuals.). (INSEE and Ministry of Defence, computed by author)

For some time the IVQ survey and JDC tests have not been testing the same literacy competences, and have not been classifying all young people from the same test sample in the same way (facing difficulties or not). Nonetheless, while the two statistical sources do not provide exactly the same measure of "illettrisme", they are comparable and rank the regions in roughly the same way.

\subsection{A very useful indicator}

Despite the methodological concerns noted above, the JDC furnishes national and local literacy statistics which are used as a reference for public authority action in relation to young people. Because of the great number of attenders and their good geographical distribution, it is possible to produce test results for each French region and each French department. Every year, once the data have been gathered and analysed by the Ministry of Education, summary statistics are published by the Ministry of Defence. In comparison, the IVQ survey is carried out only every 7 years, with only a few regional extensions ${ }^{14}$ of the national sample, providing figures about adults with literacy difficulties only for these extension surveys. Because of these special circumstances JDC statistics are more often used in regional reports and regional action plans than IVQ. Table 5 provides the latest JDC results.

Fig. 2 presents JAPD-JDC statistics for the last 11 available years, for metropolitan France and one of the "départements" registering the poorest results. Since 2008 , one can note a steady reduction in rates of illiteracy, more pronounced in

14 Only five extensions have been carried out in 2011. 
Table 5 The most recent JDC results. (Ministry of Education, Ministry of Defence 2015)

\begin{tabular}{llllll}
\hline- & Participants & \multicolumn{2}{c}{ Serious difficulties } & \multicolumn{2}{c}{ Some difficulties } \\
- & Number & $\%$ & Number & $\%$ & Number \\
\hline Metropolitan France & 746,020 & 3.6 & 26,916 & 8.7 & 65,076 \\
Overseas Territories & 33,510 & 20.2 & 6768 & 35.5 & 11,884 \\
Whole France & 779,530 & 4.3 & 33,684 & 9.9 & 76,960 \\
\hline
\end{tabular}

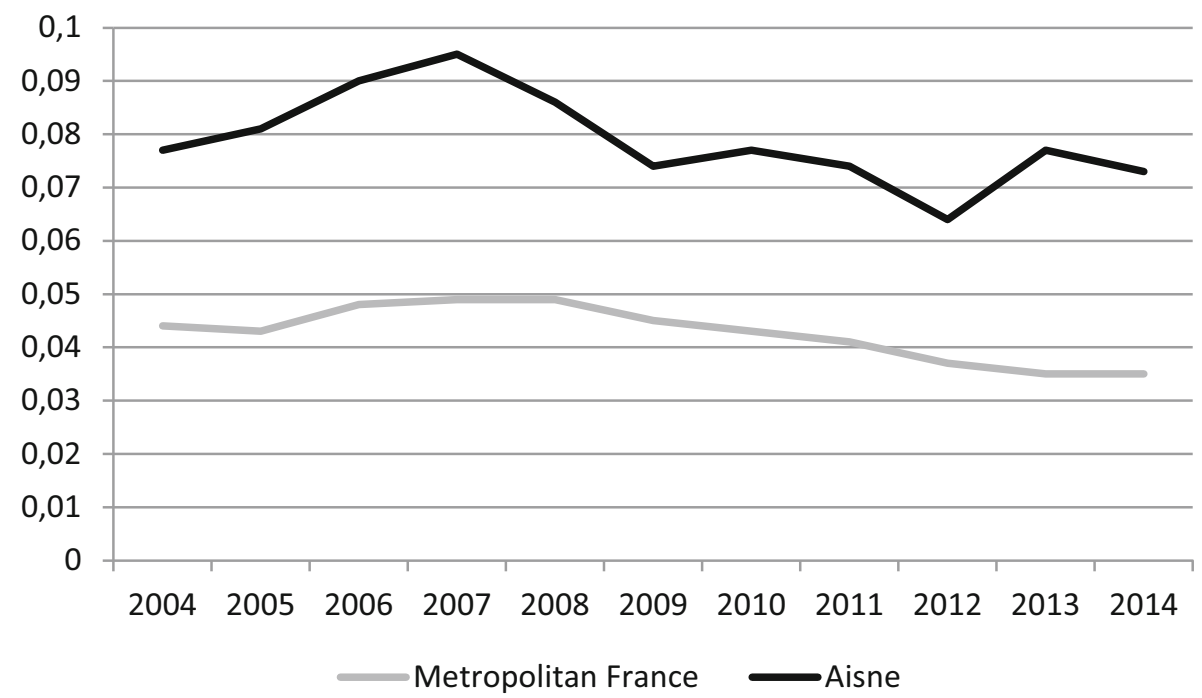

Fig. 2 "Illettrisme" rates over time in Metropolitan France and in the Aisne "département". (Ministry of Defence, computed by author)

metropolitan France as a whole than in the Aisne "département". It is this kind of information which is used at local levels.

With JDC data it is possible also to draw a quite precise geographical portrait (Fig. 3) of the difficulties in reading or of the phenomenon of "illettrisme".

In Fig. 3, we can see that the departments registering the highest levels of young French people facing strong reading difficulties are located in the North of France (former industrialised region with mines, steel industry and textile industry), the Centre (agricultural area) and the Overseas regions (75.4\% in Mayotte, $31.1 \%$ in Martinique, for example). The Paris area is one of the regions where the JDC difficulty rates are lower. This could be a surprise for professionals in the field, such as teachers, but we have to keep in mind that only French young people are attending JDC. The Paris area is the first region for migration, which partly explains why the illiteracy rate, as measured with IVQ for the whole population, regardless of nationality, is the highest in Metropolitan France (Jeantheau 2015). 


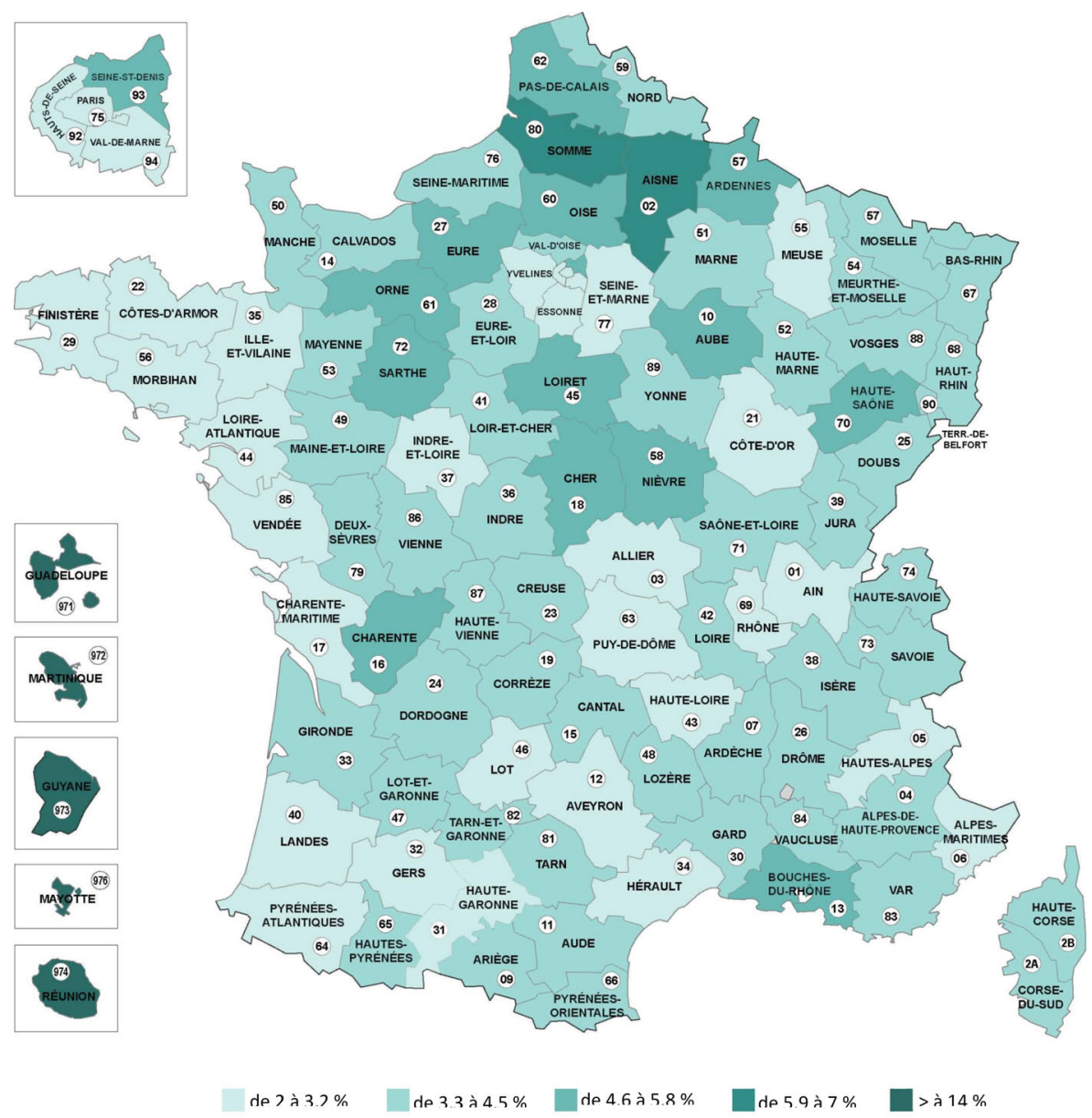

Fig. 3 Serious literacy difficulties (profiles 1-2) according to JDC 2014 by "département". (Ministry of Defence, computed by author)

\subsection{Political impact}

The JDC summary statistics are published annually by the Ministry of Education's Directorate for Evaluation, Forecasting and Performance (DEPP). They inspire neither particular emotion nor heated debates, even though they are regularly quoted to support various positions. Since they are published by region and by "départements", they mostly play a role in discussions on a more local level. They are also used as indicators by the regions to plan and monitor regional policies (regional plans for the fight against "illettrisme" in particular). Since their target population is very specific (17-19 years old in practice), they are in direct competition on the national level with the Ministry of Education's figures concerning students leaving 
school with no qualifications and with the IVQ figures that cover the entire adult population from 18 to $65 . .^{15}$

The large size of the sample (in fact almost the whole cohort) and the ease of geographical localisation of the persons ${ }^{16}$ facing literacy difficulties enable JDC to provide stakeholders with figures for relatively small territorial units (departments, small towns, neighbourhoods of the large cities). Therefore, JDC statistics are commonly used to argue for literacy projects in regions and local areas, and are guidelines for regional plans for fighting illiteracy implemented by the ANLCI Regional Project Managers and signed up to by all the partners who try to improve the literacy skills of the local population. Many articles are written every year quoting the JDC, an estimate could be thousands. This profusion of quotations shows that the regular publication of JDC results encourages the debate on "illettrisme" and low levels of literacy in France. But we have to keep in mind that statistics are not the primary objective of JAPD-JDC, they are only a by-product of an operation to give young people facing reading difficulties an additional chance to develop their literacay skills.

\section{Post JAPD-JDC issues}

\subsection{Post JDC impact for young adults}

One of the main goals of the JDC after identifying young adults with literacy difficulties is to convince them to start a learning programme again, before they themselves eventually accept after multiple failures the need to improve their literacy skills. So, after identifying young adults facing literacy difficulties, the question posed by the military is "What can we do for them?"

The JAPD offered the young people identified as having very poor literacy skills the opportunity to meet with an adult to talk about their future, receive information and careers guidance, and enter a support process (of their choice) led either by the national education system or by other bodies, depending on whether or not the person had left school. The initial process, however, did not provide any concrete support to youngsters identified as having literacy problems, but merely told them that they needed to take literacy development courses and gave them addresses ("Missions locales") where they could meet a specialist who could provide them with advice to devise an individual education programme. A letter was also sent to those who gave their approval to this, giving them the same advice and addresses.

The evaluation of this process showed very quickly that a lot of young adults who attended the interview never consulted the "Missions locales", and that only a few of the latter actually devised a personalised remedial programme in response. The main reasons discovered were: lack of motivation on the part of youngsters to meet with an army representative (not specially trained for this kind of interview), the waiting period between the interview and the reception of the letter, between the interview

15 The first two data sources (JDC and Ministry of Education data files) were linked in 2015.

16 Since 2014. 
and the contacts with "Mission locales", and between first contact with "Mission locale" and the skills evaluation carried out by a training professional. The causes could be summarized by over-bureaucratic functioning of the JAPD process and the "Missions locales". These findings led DSN to improve the process of "identifying" illiterate youngsters to their schools and to local organizations in charge of the integration of young adults under 25 (such as "Missions locales"). For example, the average waiting time between interview and reception of the official letter fell from one month to a few days. But, beyond improving administrative efficiency, it is the collaboration with external partners which makes the JDC a success.

An experiment carried out in 1998, led by the just retired General Fassier, showed that if after detection young people promptly met with trainers a large number of them would start a learning process. During the experiment involving 4 JAPD sites, trainers (from private or associative training organizations) accompanied the person from the Ministry of Defence in charge of the post-testing interview. An appointment was made during the interview for a meeting in the training organisation or elsewhere, one or two days later. The results were spectacular. Most of the youngsters attending the programme entered a training scheme, compared with fewer than $5 \%$ of those that did not attend. But it proved impossible to replicate the study at national level.

\subsection{Post JDC impact in the literacy field}

To monitor the post JDC aspects (how to take care of young adults identified as facing literacy problems) a national network has been decided on, taking into account the first statements and experimentation (discussed below). The Ministry of Defence, which cannot solve the problem alone (contrary to the previous situation when there was conscription), decided to tackle the situation by organizing links between JDC tests and post JDC actions with a panel of stakeholders working in literacy promotion and focusing on young adults. After contacts, an agreement was signed between several partners.

We can say that it is because of JAPD that the association SPR (Savoirs Pour Réussir, Knowledge for Success) and the EPIDE (Etablissement Public d'Insertion de la Défense, Military public law institution for insertion) were created. They are new opportunities (different from those that pre-existed) offered to young adults with low literacy levels. Also because of JDC, secondary schools (public and private) are increasingly focusing on students with lower levels of literacy, singly or in cooperation with local authorities. Following the JDC identification, thousands of students are benefiting from retesting and personal evaluation of their educational needs.

The other positive impact of JDC is the development, in the field and at national level, of cooperation between very different stakeholders, from voluntary sector associations (such as SPR) to ministry representatives. This cooperation appears to be expanding year after year, and also to be becoming more and more fruitful.

Several early school leavers from education and training are in both the left and right paths in Fig. 4. For this reason it is not possible to give an overall total figure. 
Fig. 4 Statistical distribution of monitoring of young adults facing literacy difficulties

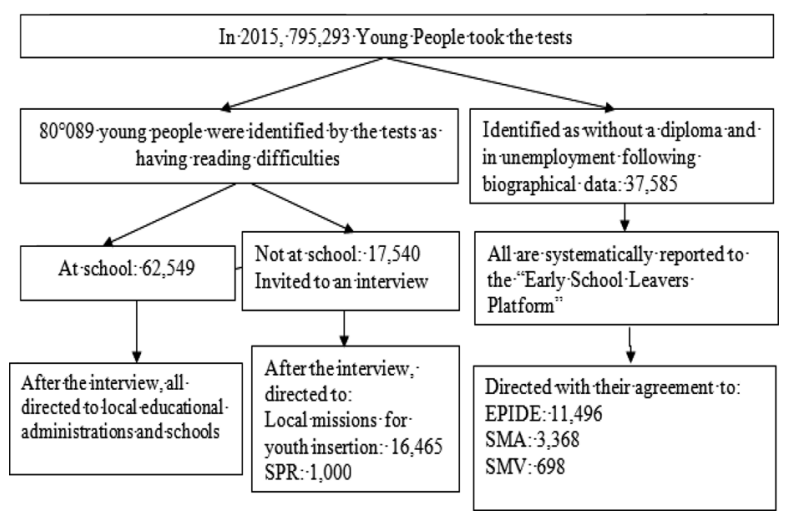

\subsection{Monitoring post JAPD-JDC partners}

As mentioned earlier, the way chosen to tackle post JAPD-JDC challenges was to develop cooperation between State Administration and Civil Society. To make the cooperation concrete, a national network was created, which enforces cooperation between all the stakeholders who act in the field and agree to join the project. The network is regulated by a range of agreements including other network partners (those which are relevant in the agreement and action context). We are going to develop the specific contribution of the main Post JDC partners in 2016.

A majority of young adults facing literacy difficulties are 17 and still at school. Consequently, the first partner of JDC is the Ministry of Education, through local education offices, schools and the central organisation. In this context, the main action of JDC staff is to inform local education offices of the test results. When information arrives in the schools, school directors have to ensure that the students reported really do have literacy problems (it is not always the case) and, if so, what kind of support has already been offered to them (the majority of cases) or should be. When students have left school the situation is more difficult even if the Ministry of Education decided on specific measures focusing on students without diplomas or with low school achievement, in the first year after they left the education system.

Amongst others, the JDC data feed the SIEI (Interministerial System of Information Exchanges), which identifies early school leavers through cross-referencing national and ministry databases. Then, nationwide monitoring and support offices advise and help early school leavers to return to education or prepare for a working life. In five years the number of young dropouts has fallen from 136,000 to 110,000. Today, the French early school leaving rate $(9 \%)$ is 1 point below the Europe 2020 Strategy target $(10 \%)$ and 2 points below the European average $(11 \%) .{ }^{17}$

Religious schools are the most numerous private schools in France, and they are mainly catholic. Since 2004 the DSN has been sending the personal data forms of students identified as facing literacy difficulties direct to the relevant body. The same protocol is used with schools under the Ministry of Agriculture (especially at

17 Source Ministry of Education. 
secondary level). Following the protocol, every school has to organize an interview with the young adults concerned, to determine what kind of support can be offered to them. As compulsory education in France ends at 16, a significant proportion of those identified have already left school. For this reason partners other than the Ministry of Education are involved in post JAPD action.

"Missions locales" are also important partners of the JDC. A "mission locale" is a space dedicated to the support of young adults aged 16-25; it provides every young adult with individual answers to their questions about employment, training, health care and housing, and offers a tutorial to define a professional project and an individual training curriculum, to get a job and to keep it. "Missions locales" are funded by local authorities (around $50 \%$ ), by the State (40\%) and by the European commission through the European Social Fund. It is also necessary to point out the agreements signed between "Missions locales" and EPIDE, SMA (Service Militaire Adapté, Adapted Military Service), SMV (Service Militaire Volontaire, Volontary Military Service) and SPR. SPR is a literacy programme carried out since 2003 by Caisses d'Epargne ${ }^{18}$ Foundation. When SPR reached its maximum development there were 23 centres in Metropolitan France, in which 1500 young adults were tutored by 500 volunteers, and 40 professionals (paid by the project). In 2016 the number of SPR centres fell to 12 (some regional centres continue to work under another name having become independent of the foundation).

Three other JDC partners are more or less linked to the Army.

The EPIDE ${ }^{19}$ was created on August 2nd 2005 by the Ministry of Defence; in 2016 it depends on the Ministry of Sports, the Ministry of Employment and the Ministry of Cities. Its mission is to lead to the professional and social integration of young adults (18-25) facing school difficulties, without qualification, unemployed, or at risk of social marginalisation. Participants are volunteers; they are allowed to stay in the EPIDE centres from 6 to 12 months. The four main aims of the EPIDE programme are socialisation, education and training, professional integration and orientation. In 2014, in 18 centres throughout metropolitan France, the 908 staff members of the institution welcomed over 3500 young people for an average support programme of 10 months. In 2016, at the request of the government, the number of young adults accepted was due to increase by $25 \%$. In 2014, $60 \%$ of the volunteers had no diploma. The majority of them left EPIDE with a diploma attesting to a level of knowledge equivalent (EPIDE 2014) to the end of primary school. Most of those leaving EPIDE get a work contract for at least 6 months. Despite its good results EPIDE has been criticised on grounds of cost.

The SMA was created in 1961. After the end of conscription the SMA continued its mission. The SMA is focused on employability, but also on the upgrading of young overseas adults (18-25) in basic skills. Engagement brings with it military status - that of an army volunteer. As such, the volunteers are housed and fed in their regiment and receive a monthly salary of just over $300 €$. In 2016 there are 7 centres Overseas and one in Metropolitan France (only for those few draftees coming from

\footnotetext{
18 Private bank foundation, created in 2001, and State approved.

19 In 2014 the EPIDE changed its name to Etablissement Public d'Insertion Dans 1'Emploi (Public Institution for the Integration of young adults in Employment) but not its acronym.
} 
overseas territories). The SMA action is based on a military framework. The training aims at the acquisition of social skills and a professional basis, but also addresses the employability of each volunteer.

The SMV is a military employability device. It is an adapted version of the SMA for metropolitan France. It is aimed at young people in trouble at school who want to bounce back through training and strict supervision. The volunteer is supported throughout the SMV (housing, food, clothing) and receives a balance of $€ 313$ net per month. The first centre opened in October 2015; seven centres are expected in 2017. The goal for 2016 is to reach 2000 volunteers.

In addition to the partners described above we could mention the Ministry of Justice, which organises JDC with young adults under Justice control, and the Association of Student Volunteers, which provides free courses to students with poor literacy skills. Encouraging cooperation between the JAPD partners is a very important part of the ANLCI's promotional activity. The different partners work together to guide young adults to the most appropriate institution or association for literacy support. Every year a special coordination meeting is organized by the DSN with the JDC partners for monitoring the JDC. It is an opportunity to exchange experiences and good practices. The first goal to be achieved is to offer a solution to every single young adult with reading problems. The second goal is to encourage those young adults to enter existing literacy programmes and to find work.

\section{Conclusion}

It is difficult to assess very precisely the impact of post JDC actions carried out by JDC partners. It is confirmed by all of them that the JDC process gives another opportunity each year to examine the basic literacy skills of each member of a complete cohort. The first beneficiaries are the young adults identified as having poor literacy skills, because they will meet with an adult (during the JDC or in their schools) who will help them confront their problems whilst offering information about how they might address them.

Numerous stakeholders are federated with JDC, coming from very different organisations and working together for better coordinated action. The JDC tests and the post JDC actions are not perfect, but through increasing stakeholder cooperation, the efficiency of each partner increases, making the global effort more productive. JDC impact is far more than the results of the 25 minutes of literacy tests, it is the discovery of other partners, and of their work, their values, the understanding of their goals and methods, the exchange of points of view and practice, the research of coordination of actions to increase the effectiveness of each one, to provide young adults with literacy problems maximum support in a region of the world which decided to be more advanced on the path to the knowledge society.

The JDC experience shows that it is possible to take account of literacy problems and to implement literacy identification in a nationwide programme which is not principally literacy-oriented. This choice is a way to make public investment more efficient and to create support for synergies between organizations working in the literacy field. 
Open Access This article is distributed under the terms of the Creative Commons Attribution 4.0 International License (http://creativecommons.org/licenses/by/4.0/), which permits unrestricted use, distribution, and reproduction in any medium, provided you give appropriate credit to the original author(s) and the source, provide a link to the Creative Commons license, and indicate if changes were made.

\section{References}

ANLCI (2003). Lutter ensemble contre l'illettrisme. Cadre national de référence. (Fighting Illiteracy Together, National Guidelines). Lyon: ANLCI.

Beaudelot, C., \& Establet, R. (1988). Le niveau intellectuel des jeunés conscrits ne cesse de s'élever (the intellectual level of conscripts is constantly increasing). Economie et statistique, 207, 31-39.

Cariat, M.J.A.N. de (Condorcet) (1791). Cinq mémoires sur l'instruction publique, (Five Projects for Public Education), Buisson, Paris.

Direction du Service National (2015). Rapport annuel d'activité (annual overview of activities). Paris: Ministère de la Défense.

EPIDE (2014). Bilan d'activité, (Overview of activities). Malakoff: Epide.

Espérandieu, V., Lion, A., \& Bénichou, J.-P. (1984). Des Illettrés en France ("Illettrés” in France). Paris: La Documentation française.

Furet, F., \& Sachs, W. (1974). La croissance de l'alphabétisation en France (XVIIIe-XIXe siècle) (The growth of alphabetization in France). Annales, Economies, Sociétés, Civilisations, 3, 714-737.

Jeantheau, J.-P. (2006). Assessing low levels of literacy in france. Literacy and Numeracy Studies, 14(2), 75-92.

Jeantheau, J.-P. (2014). The national survey IVQ a basis for an indicator net and an opportunity for research. In The methods and Applications of Research on Literacy, NIKL (National Institute of the Korean Language), Seoul.

Jeantheau, J.-P. (2015). What lessons can be drawn from the evolution of the state of adult literacy in France? In A. Grotlüschen \& D. Zimper (Eds.), Literalitäts- und Grundlagenforschung (Alphabetisierung und Grundbildung) (vol. 11, pp. 177-196). Münster: Waxmann.

Jeantheau, J.-P., \& Guillon, V. (2010). Mesure comparée de l'illettrisme, (comparative measurement of "illettrisme"). Paris: INSEE.

Jeantheau, J.-P., \& Murat, F. (1999). Les évaluations en lecture dans le cadre des journées d'appel de préparation à la défense (Reading assessment during the compulsory military call-up days). Paris: Note d'information.

Ministère de l'éducation (Ministry of Education) (2015). JDC 2015, un jeune sur dix handicapé par ses difficultés en lecture, (JDC 2015, one in ten young adult facing readingdifficulties). vol. 16. Paris: Note d'information.

National Research Council (2005). Measuring literacy performance levels for adults. Washington: National Academies Press. 